\title{
Proteomic Analysis of Serum in Lung Cancer Induced by 3-Methylcholanthrene
}

\author{
Minhua Li, Bo Ye, Yuxia Zhang, Honglei Chen, Dong Xia, Mingqiu Liu, and Fei Yang \\ Department of Pathology, Medical College, Wuhan University, No.185 Dong-Hu Road, Wuhan 430071, China \\ Correspondence should be addressed to Fei Yang, yangfei72@hotmail.com
}

Received 9 February 2009; Revised 31 May 2009; Accepted 3 July 2009

Recommended by Eric W. Lam

\begin{abstract}
Lung cancer remains the leading cause of cancer-related mortality worldwide. Early detection of lung cancer is problematic due to the lack of a marker with high diagnosis sensitivity and specificity. To determine the differently expressed proteins in the serum of lung cancer and figure out the function of the proteins, two-dimensional electrophoresis (2DE) and matrix-assisted laser desorption/ionization time-of-flight mass spectrometry (MALDI-TOF-MS) were used to screen the serum proteins of lung cancer model induced by 3-methylcholanthrene (MCA). From optimized 2DE image, 455 spots in the normal sera and 716 spots in the lung cancers sera were detected. Among them, 141 protein spots were differentially expressed when comparing the serum from normal rat and serum from lung cancer model, including 82 overexpressed proteins and 59 underexpressed proteins. Changes of haptoglobin, transthyretin, and TNF superfamily member 8 (TNFRS8) were confirmed in sera from lung cancer by MALDI-TOFMS. Proteomics technology leads to identify changes of haptoglobin, transthyretin, and TNFRS8 in serum of rat lung cancer model and represents a powerful tool in searching for candidate proteins as biomarkers.
\end{abstract}

Copyright (C) 2009 Minhua Li et al. This is an open access article distributed under the Creative Commons Attribution License, which permits unrestricted use, distribution, and reproduction in any medium, provided the original work is properly cited.

\section{Introduction}

Nowadays, lung cancer is one of the most common malignant tumors. Statistics demonstrate that, in the past 20 years, with the development of industry and aggravation of air pollution, the morbidity rate and mortality rate of lung cancer are increasing most quickly in all malignant tumors in China. In cities, the mortality of lung cancer is 27.5/1000 000, accounting for 22.4/100 of all death in malignant tumors [1]. The five-year survival rate is 14/100 in America, less in China. Besides the reasons of environment pollution, smoking, heredity, lack of early diagnostic tools is also the important factor which contributes to that bad situation. In the recent years, with the development of biology and imageology, for example, spiral CT, cytological examination of sputum and endoscopy of bronchus, and so on, positive rate of early diagnosis is increasing but there are related limitations in all kinds of methods. Maybe they lead to missed diagnosis in early lung cancer. The sensitivity of fine needle aspiration biopsy (FNAB) in diagnosis of malignant nodes is $70 / 100-100 / 100$ [2], but it may destroy some normal tissues and bring about some complications, for instance, pneumatothorax and hemoptysis. Blood plasma is the most easily controlled and acquired specimen. So making use of serum sample to detect special markers is the most perfect method in diagnosis of clinical lung cancer. The reasons why we choose the blood plasma as the pathfinder of proteome research are as follows. (i) Serum proteome is the most complicated proteome, including inferior proteome in different tissues. (ii) It is easy to obtain enough serum proteins as research sample and it is easy to be standardized. (iii) There is a large range of dynamic state in property of serum proteins. (iv) There is no strict linear relationship between the expression levels of the mRNAs and proteins. The modification after translation, such as glycosylation and phosphorylation, is more and more popular, so it is necessary to globally analyze the secreted proteins expressed by cells or tissues.

In the research of neoplastic serum proteomics, the related proteomics technology is principally used to fathom the change of serum proteins in the course of forming tumor, to screen and discover the tumor markers and potential drug targets which could be used for classification, early diagnosis, therapy, and intervention of the tumor. Nowadays, two technical modes are often applied in the research of 
serum proteomics: (i) surface-enhanced laser desorption and ionization take-of-flight mass spectrometry (SELDITOF-MS), (ii) matrix assisted laser desorption/ionization time-of-flight mass spectrometry (MALDI-TOF-MS). The new generation of MALDI-TOF-MS could quickly, exactly identify polypeptides and proteins with high sensitivity and high throughput. There are many advantages: (i) Small needed quantity (fmol), (ii) short time of analysis (3-5 minutes), (iii) high accuracy of quality (1/10000), (iv) the immunity to the effect of N-terminal close, (v) making use of situ-enzymolysis-technology could directly identify the protein spots which are cut from gels. So it reduces the loss of specimen, (vi) it could identify a single protein in protein mixture and directly identify the modification after translation $[3,4]$. So it develops quickly and becomes the preferred way of analyzing polypeptides and proteins in laboratory. In our research, we made the rats our lung cancer model which was induced with MCA, used the method of 2DE combined with MALDI-TOF-MS, made compared serum proteomics research in lung cancer, analyzed the changes of serum proteins before and after the formation of lung cancer in same body, identified serum proteins which related to lung cancer for offering serum proteomic evidence to probe the pathogenesis of lung cancer as well as providing new style to probe hematological diagnostic method of lung cancer.

\section{Materials}

2.1. Animals. 20 Wistar rats (10 male, 10 female) were purchased from Experimental Zoology Department at Tongji Medical College in Huazhong Technology University. They ranged in weight from $180 \mathrm{~g}$ to $200 \mathrm{~g}$.

2.2. Reagents. 3-methylcholanthrene (MCA) was the product of Sigma (Sigma-Aldrich, Inc, Saint Louis, Missouri, USA), immobilized $\mathrm{pH}$ gradient Dry strip was purchased from Amersham Pharmacia Biotech Company, sodium dodecyl sulfate (SDS), dithiothreitol (DTT), tris(hydroxymethyl) aminomethane (Tris), bromophenol blue (BPB), ammonium persulfate (APS), Glycine, Acrylamide, Methylene bisacrylamide (BIS), tetramethylethylenediamine (TEMED), IPG-Buffer, Drystrip cover fluid, Agarose, Carbamide, protein-markers were purchased from A-Pharmacia Co., coomassie brilliant blue R-250, 3-[(3-cholamidopropyl)dimethylammonio]-1-propanesulfonate (CHAPS) were purchased from Sigma Co., Glacial Acetic Acid, methanol, glycerol, paraform, alcohol were national analytical pure, sequencing-grade modified trypsin was purchased from American Roche Co., $\alpha$-cyano-4hydroxycinnamic acid (CCA) (Sigma Co.), acetonitrile (ACN) (Fisher chromatographic pure), Tri-Fluoro-aceticAcid (TFA) (Sigma Co.). Water was Milli-Q ultrapure water.

2.3. Major Equipments. IPGphor isoelectric focusing electrophoretic apparatus was purchased from Swedish Amersham pharmacia Biotech Co., PROTEANXI Cell vertical electrophoretic apparatus was purchased from BIO-RAD
Co., Image Scanner was purchased from Swedish Amersham pharmacia Biotech Co., CentriVap Centrifugal Concentrators and Cold Traps were purchased from LABCONCO Co., Spotcutter apparatus was purchased from BIO-RAD Co., and Autoflex MALDI-TOF-MS mass spectrometry apparatus was purchased from Germany BRUKER Co.

2.4. Ancillary Software. Image Master IDE software and MASCOT software are found in http://www.matrixscience .com/search_form_select.html.

\section{Methods}

3.1. Induction of Lung Cancer Model. The rats were kept in cozy $\left(15-25^{\circ} \mathrm{C}\right)$, quiet and avoided of highlight for 58 hours before making the experiment. The rats were kept for 14 days after the whole blood was collected by heart puncture. Then we made the model of lung cancer induced with MCA in iodized oil by intrabronchial installation [5, 6] with minor modifications. The details were as follow: Iodized oil $0.1 \mathrm{~mL}$ containing MCA $10 \mathrm{mg}$ was dissolved at $76-78^{\circ} \mathrm{C}$ for 24 hours. As the basal anesthesia, Ketamine hydrochloride $0.12 \mathrm{~mL}$ was injected into the muscle of right thigh $(0.6 \mathrm{~mL} / \mathrm{kg})$, at the same time, penicillin $20000 \mathrm{u}$ and phytomycin $50 \mathrm{mg}$ per rat were injected into the muscle of left thigh once a day for a week for infection prevention. After about 2-3 minutes, early drugged state was showed up, and then the rats were anaesthetized with diethylether for relaxing the muscle of laryngeal. The anaesthetized rats were put on a consple with $45^{\circ} \mathrm{C}$ inclined plane and the upper jaw incisor teeth were fixed by a retention suture on superior extremity of table top. The throat was exposed with gripping tweezers and bended tongue spatula with elastic metals. In a frontal mirror, at the moment of inspiration, the injection needle with blunt end in $1 \mathrm{~mL}$ syringe was inserted in glottis until reached the crotch of trachea, then turned left bottom to lobar bronchi in inferior lobe of left lung, and then iodized oil $0.1 \mathrm{~mL}$ with MCA $10 \mathrm{mg}$ was injected. Take pictures with DSA after installation for a day to find the location of iodized oil with MCA. Sacrificed the animals after installation for 180 days dissected the rats systematically and took the tissues where pathological changes were obvious and all organs, metastasis, lymph nodes with suspected of invasion, fixed them with paraform, embeded them with paraffin wax, sliced them, and stained with HE.

3.2. Serum Sample Preparations. The rats were raised with skins of hind neck in order that the limbs could downward sagging after they were anesthetized with diethylether. The injector that contains heparin was used to pump blood $(1-3 \mathrm{~mL})$ on the left chest wall where the heart beats most powerfully $(1.5-2 \mathrm{~cm}$ higher than the lower margin of ensiform cartilage). The blood was kept in centrifuge tube for 30 minutes at room temperature, centrifuged at $2000 \mathrm{rpm}$ for 15 minutes. The plasma was taken out and aliquoted into sterile EP tubes, stored at $-70^{\circ} \mathrm{C}$ until used.

Ten rats with lung cancer were chosen by pathological diagnosis. $50 \mathrm{uL}$ plasma was taken out, respectively, before 
and after the formation of lung cancer, then combined and quantified with Bradford method, followed by taking $1 \mathrm{mg}$ protein used for isoelectric focusing.

3.3. 2-DE. All measurements were performed as described previously [7] with minor modification.

3.3.1. IEF. In the first dimension, proteins were separated by IEF with IPG strip (pH3-10, nonlinear gradient and $\mathrm{pH} 4-$ 7 , linear gradient, both $180 \mathrm{~mm} \times 3 \mathrm{~mm} \times 0.5 \mathrm{~mm}$ ). Of the total proteins, $1 \mathrm{mg}$ was dissolved in lysis buffer ( $8 \mathrm{M}$ urea, 0.02 CHAPS, 0.02 M DTT, 0.05 IPG buffer) to obtain a total volume of $350 \mathrm{uL}$ per strip. Focused IPG were rehydrated at $30 \mathrm{v}$ for 6 hours, at $500 \mathrm{v}$ for 1 hour, at $1000 \mathrm{v}$ for 1 hour, and at $8000 \mathrm{v}$ for 10 hours.

3.3.2. Balance. After IEF, IPG strips were washed with Milli-Q water and then incubated in equilibration buffer (30\% glucerin, $6 \mathrm{M}$ urea, $2 \% \mathrm{SDS}, 50 \mathrm{Mm}$ Tris-HcL pH 8.8, trace bromophenol blue) containing $20 \mathrm{mM}$ DTT on rocking bed for 15 minutes, followed by 15 minutes incubation in the same equilibration buffer containing $100 \mathrm{mM}$ Iodoacetamide on rocking bed.

3.3.3. SDS-PAGE. The second vertical SDS-PAGE was performed in PROTEANXI CELL. Equilibrated IPG strips were placed on top of a 13\% homogeneous SDS-polyacrylamide gel. A scrap of filter paper was immersed in $10 \mathrm{uL}$ protein marker and put on top of one side of the gel. The edge was sealed with $0.5 \%$ agarose. $13 \%$ SDS-PAGE gels $75 \mathrm{~mL}$ contained $30 \%$ ACR $/ 0.8 \%$ BIS $33.5 \mathrm{~mL}, 4 \times$ Tris-HCL $19.5 \mathrm{~mL}$ pH 8.8, Milli-Q water $24.5 \mathrm{~mL}, 10 \%$ APS $0.25 \mathrm{~mL}$, TEMED $0.05 \mathrm{~mL}$. Gels were run in parallel at constant power ( $40 \mathrm{~mA}$ for 40 minutes, $60 \mathrm{~mA}$ for 5 hours) in running buffer until BPB reached the bottom line of each gel.

3.3.4. Protein Staining. The gels were put into $0.1 \%$ coomassie brilliant blue solution (methanol $484 \mathrm{~mL}$, glacial acetic acid $92 \mathrm{~mL}$, Milli-Q water $454 \mathrm{~mL}$, Coomasie brilliant blue R-250 1 g) and stained on rocking bed for 3 hours. After pouring out the coomassie brilliant blue solution, we decolored them in depigmenting agent solution (methanol $50 \mathrm{~mL}$, glacial acetic acid $75 \mathrm{~mL}$, Milli-Q water $875 \mathrm{~mL}$ ) for 24 hours until the background of gel pieces became clear and transparent.

3.3.5. Image Analysis. Gel images were scanned with Image Scanner. Spots detection, quantification, matching and comparison of 2DE protein pattern were done with Image Master IDE software. In the protein matching, serum protein gel maps of normal controls were regarded as referenced gel, artificial matched spots were built up, and the analysis of different expression was performed by applied software. The abundance of each protein spot was estimated by the percentage volume. The individual spot volumes were normalized by dividing their intensity values by the total intensity values of all the spots present in the gel and expressed as $\%$ vol. If the ratio of relative content in different group was more than 2 or less than 0.5 , we could assess there were differences.

3.4. Protein Identification by MALDI-TOF-MS. It was carried out by the procedure described in detail previously [7] with minor modification.

3.4.1. In-Gel Digestion. We chose 13 differently expressed protein spots with clear margin and high abundance protein. Of all the spots, 7 protein spots were overexpressed, 4 protein spots were underexpressed, and 2 protein spots were new in the plasmas of lung cancer. The chosen protein spots in 2DE maps were excised with spot-cutter apparatus and transferred into $1.5 \mathrm{~mL}$ EP tube, followed by washing them thrice with $1 \mathrm{~mL}$ water for 10 minutes. Gel pieces were discolored in 50-100 uL solution (50\% acetonitrile, $25 \mathrm{mmol} / \mathrm{L}$ ammonium bicarbonate) for 20 minutes with constant oscillation, followed by discarding the solution, repeated 1-2 times until blue color disappeared, dried them in vacuum centrifugal dryer for 30 minutes. Then $5-10 \mathrm{uL}$ of $0.01 \mathrm{ug} / \mathrm{uL}$ trypsin diluted in $25 \mathrm{mmol} / \mathrm{L}$ ammonium bicarbonate was added to each sample tube for digesting the proteins and kept the tubes in freezer at $4{ }^{\circ} \mathrm{C}$ for $20-30$ minutes. After all digestion solution was ingested, 5-10 uL of $25 \mathrm{mmol} / \mathrm{L}$ ammonium bicarbonate was added to it. Stored it at $37^{\circ} \mathrm{C}$ for 15 hours. The digested polypeptides were eluted twice with $5 \%$ TFA $50-100 \mathrm{uL}$ at $40^{\circ} \mathrm{C}$ for 1 hour and $2.5 \%$ TFA, $50 \%$ ACN $50-100 \mathrm{uL}$ at $30^{\circ} \mathrm{C}$ for 1 hour, supernatants were collected, combined, vacuum-dried by centrifugation until used for mass spectrographic analysis.

3.4.2. Preparation of Peptide Mass Fingerprinting. $5 \mathrm{uL}$ of $0.5 \%$ TFA was added to dried sample tubes for dissolving the peptides mixture. The sample and ground substances (CCA added to $30 \% \mathrm{ACN}$ or $10 \%$ aceton to obtain saturated solution) were combined with 1:1 volume and spotted onto the target plate, then air-dried.

3.4.3. The Detection of Peptide Mass Fingerprinting. Peptide mass fingerprinting spectrum was evaluated with a reflector positive ion model in following setting: accelerating voltage, $20 \mathrm{KV}$; reflected voltage, $1.12 \mathrm{KV}$; nitrogen laser wavelength, $337 \mathrm{~nm}$; pulse width, 3 nanoseconds; delayed extraction time, 100 nanoseconds; the degree of vacuum, $4 \times 10^{-7}$ Torr; each spectrum was obtained by accumulating 50 laser shots and averaging them. A matrix peak and a trypsin autodigestion fragment peak served as an internal calibration standard.

3.4.4. MALDI-TOF-MS Analysis. It was performed to analyze the peptides. The peptide mass fingerprinting of each protein was searched from NCBInr database using Mascot software. The functions of the identified protein were searched by NCBI protein databanks. The conditions of searching are as follows (i) The peptides mass were controlled between $800 \mathrm{Da}$ and $4000 \mathrm{Da}$. (ii) The sphere of error in apparent pI and apparent $\mathrm{Mr}$ was $+0.5 \mathrm{pH}$ and $\pm 20 \%$. (iii) The largest error in molecular weight of peptide fragment 


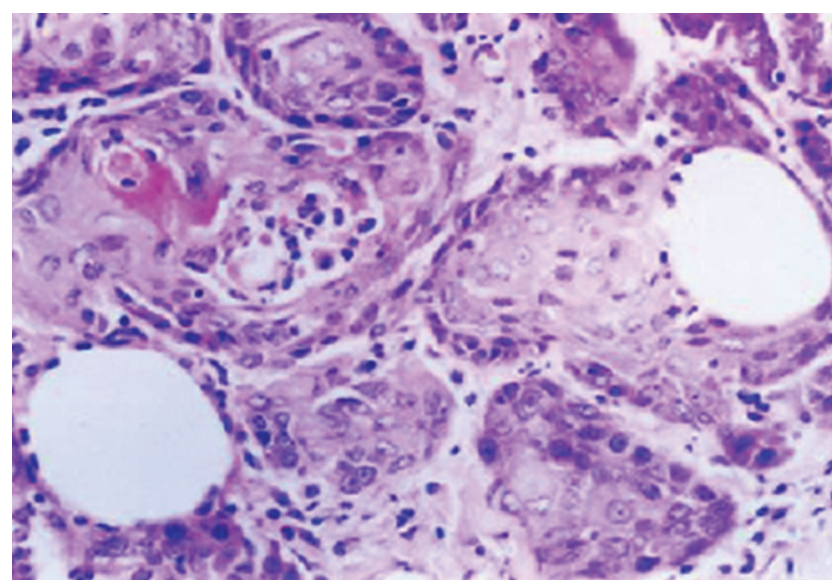

Figure 1: The lung cancer specimen induced by MCA, showing that the carcinoma cells formed nests in which the red horny pearl was obvious; carcinoma cell nucleus were very big and vacuous, and nucleoli were big and localized to the edge. $\mathrm{HE} \times 200$.

was controlled in the range of $-0.3 \mathrm{Da}$ to $+0.3 \mathrm{Da}$. (iv) The trypsin was chosen as the enzyme and the incomplete choice of enzymolysis fragment was 1 or 2. (v) Mattus was chosen as species resource. (vi) The peptide ions were $[\mathrm{M}+\mathrm{H}]^{+}$and monoisotopie. (vii) The number of smallest matched peptide fragment was 4 . (viii) There were not limitations in the fixed modification. The variable modification was oxidation.

\section{Results}

Lung cancer models were made successfully after installing MCA in iodized oil. It was demonstrated that iodized oil was present in the inferior part of left pulmonary lobes by scissors shadow with $\mathrm{X}$-ray. Only in ten rats of 18 rats (two rats died naturally in 20 rats), tubercles in bottom left of pulmonary lobes were observed in naked eye. By pathological examination, it was proved that they were squamous cell carcinomas. The rate of induced-cancer was 55\%. After HE staining, by light microscope, we could observe that carcinoma nests were different in size and shape, the horny pearl was obvious, cell nucleus were very big, part of them were vacuous, the chromatins in cell nucleus were rough, there were many karyokinesis, and nucleoli were big and localized to the edge (Figure 1).

The good reproducible results were acquired using the optimized 2DE technique. The electrophoresis of plasma in 10 animal models was performed before and after forming lung cancer, respectively. The protein spots were separated better using pH4-7 IPGIEF (Figure 2(b)) than pH3-10 IPGIEF (Figure 2(a)). The distribution patterns of all proteins were similar. The protein spots in the range of pI4-6 and Mr10-65 kD were distributed most intensively.

When making an analysis of 2DE patterns which were separated with pH4-7 IPG strip (Figure 3), we found that 455 spots on the normal plasmas $2 \mathrm{DE}$ patterns and 716 spots on the lung cancer plasmas 2DE patterns were detected. When we matched the lung cancer plasmas 2DE patterns with the normal plasmas 2DE patterns, it was demonstrated that the number of matched protein spots was 295 and matched rate was $50.38 \%$.

141 protein spots were differently expressed significantly in plasmas $2 \mathrm{DE}$ patterns, 82 spots overexpressed in the lung cancer and 59 spots overexpressed in normal controls. We chose 13 differently expressed proteins spots with clear margin and high quantity of proteins for MALDI-TOFMS analysis. Of all the protein spots, 7 protein spots were overexpressed (numbers 1, 2, 3, 4, 7, 8, 9), 4 protein spots were underexpressed (numbers 10,11, 12, 13), 2 protein spots were new in the plasmas of lung cancer (numbers 5, 6) (Figures 4 and 5).

The peptide mass fingerprinting maps were obtained successfully by analysis of MALDI-TOF-MS after digesting the chosen protein spots. Finally, 3 proteins were identified through the NCBInr database search by Mascot software in chosen 13 protein spots.

The 3 proteins were heptoglobin (overexpressed protein), transthyretin (underexpressed protein), and tumor necrosis factor receptor superfamily member 8 (new protein). The figures were the mass spectrum of identified proteins spots and detailed results of database retrieval (Figures 6, 7, 8, 9, 10 , and 11).

\section{Discussion}

MCA is an indirect chemical carcinogen, which belongs to polycyclic aromatic hydrocarbon with 3, 4-benzpyrene, and is responsible to air pollution. Its major effect is to make epithelium mucosae cell of bronchiole, respiratory bronchiole squamous metaplasia and gradually progress to squamous carcinoma cell. We had proved that there were a series of changes of genetic materials and related genes in the process of variation from normal bronchi epithelium to lung squamous carcinoma cell by immunohistochemistry staining and molecular pathology $[8,9]$. For example, the different positive expression rate of $\mathrm{P} 53$ protein was $69.57 \%$ in rat lung cancer tissue. The positive expression rate of proliferative cell nuclear antigen (PCNA) took up 20\% in normal bronchi epithelium tissue, and it advanced to $82.61 \%$ in infiltrating lung cancer tissue. In addition, the number of strong positive expressed cells was increasing obviously, even all carcinoma nests were positive expressed, it hinted the changes of activity of cell proliferation during the formation of lung cancer. Thus making use of the model of rat lung cancer to carry out serum proteome research was effective and feasible.

Haptoglobin, one of acute phase proteins, is an acid glycoprotein, which belongs to $\alpha_{2}$-globulin and extensively exists in human plasmas and other body fluid. Most of $\mathrm{Hp}$ is synthesized in liver. In addition, Hp mRNA is also expressed in human endometriotic lesions, intestinal epithelium and mouse liver, lung, adipose tissue cell, skin [10]. Friedrichs et al. [11] found that $\mathrm{Hp}$ mRNA was detected in some special cells of adernal gland, submandibular gland, ovary, ureter. Mi-Kyung et al. [12] further proved that Hp was considered as a secretory protein, however, Hp synthesized in THP-1 monocytic cells was largely retained within cells. 


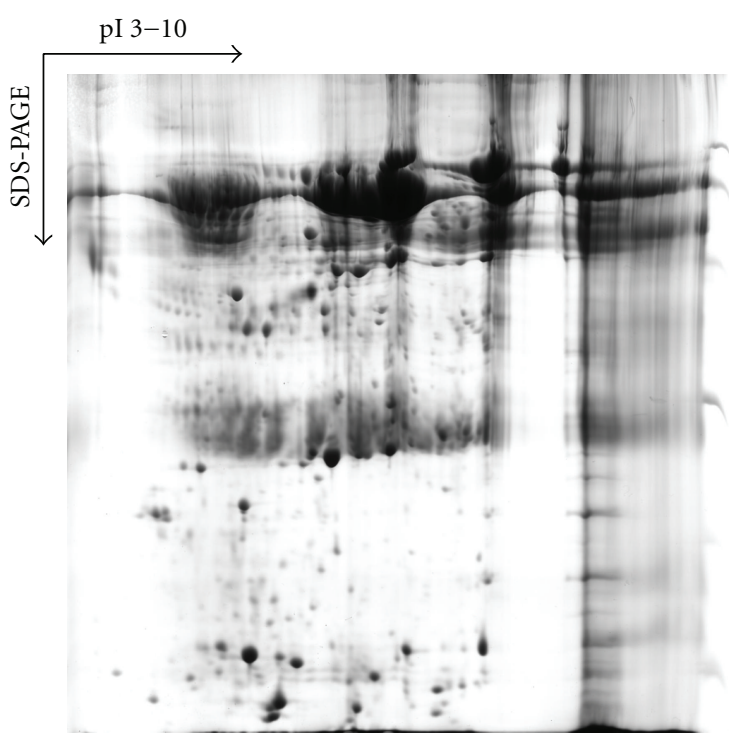

(a)

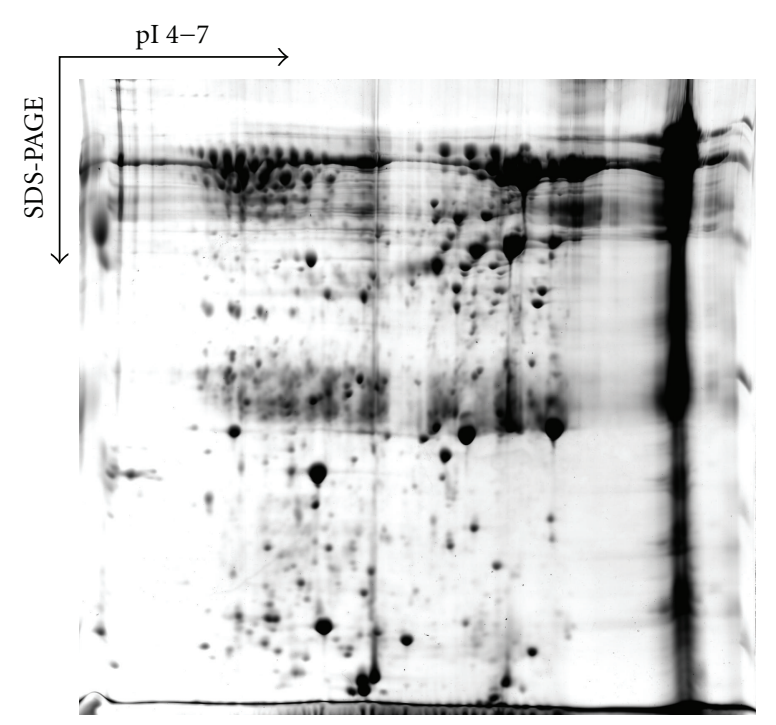

(b)

FIGURE 2: 2DE patterns after lung cancer formation. They were acquired by separating plasma of rats with lung cancer using pH3-10 (a) and pH4-7 (b) IPG strips, showing there were many protein spots and the number of protein spots in (a) was more than that in (b) obviously.

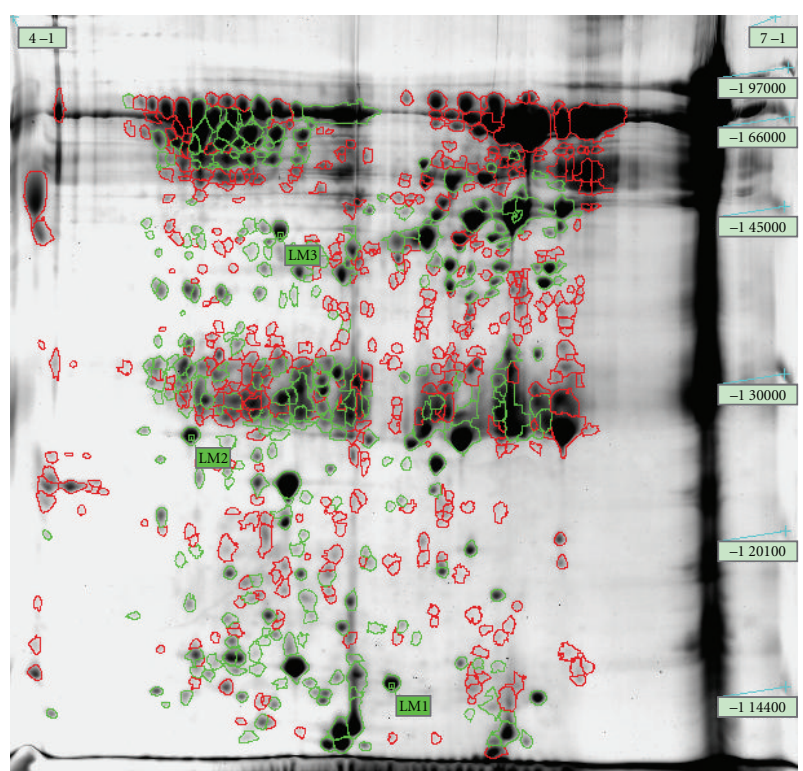

FIGURE 3: Analysis of 2DE protein matching after the formation of lung cancer ( $\mathrm{pH} 4-7)$. The green spots were the matched protein spots and the red spots were the unmatched, the number of matched proteins was 295 .

And Hp was degraded mainly in liver as well. The content of $\mathrm{Hp}$ in plasmas often greatly increases in pathologic state, for example, carcinoma, inflammation, infection, myocarditis, and so on. The extent of severity correlates with prognosis. The expression of $\mathrm{Hp}$ is accommodated by lipopolysaccharide, cytokine, hormone [10]. The main factor stimulates the composition of Hp is IL-6. On the condition of inflammation, injury, IL-1, TNF are secreted by macrophage, leading to the increase of IL-6, resulting in the composition of Hp. In addition, D'Armiento [13] proved that Lps also could stimulate the expression of $\mathrm{Hp}$ mRNA. Mi-Kyung et al. [12] proved protein kinase-c-delta could stimulate haptoglobin secretion as well. By forming the high-affinity complexes, Hp could bind free hemoglobin ( $\mathrm{Hb}$ ). In turn, these $\mathrm{Hp}-\mathrm{Hb}$ complexes could bind to the CD163 scavenger receptor on macrophages with high specificity, leading to endocytosis and subsequent intracellular degradation. So $\mathrm{Hp}-\mathrm{Hb}$ complex formation is considered to lessen the loss of free $\mathrm{Hb}$ through glomerular filtration and it is helpful for supporting the recycling of iron. Moreover, because free $\mathrm{Hb}$ is a source of iron, which may otherwise enhance bacterial growth and virulence, so it is important that $\mathrm{Hb}$ released from erythrocytes could be cleared promptly. Finally, free $\mathrm{Hb}$ could release heme and iron which may participate in generating reactive oxygen species (Fenton reaction) and promote the injury of tissue as well. In a word, Hp works indirectly as a bacteriostatic agent and an antioxidant in the way of facilitating the immediate clearance of free $\mathrm{Hb}$ by macrophages [14]. Haptoglobin polymorphism correlates to the prevalence and clinical evolution of many inflammatory diseases, for example, infections, atherosclerosis, and autoimmune disorders [10] and that leads to the generation of two distinct alleles, Hp2-1, Hp1-1, and Hp2-2. Hp2-2 has been reported to be associated with the risk of atherosclerosis and coronary heart disease. Vormittag et al. [15] proved that Hp2-2 was a potentially new risk factor for spontaneous venous thromboembolism as well. There are many researches about Hp correlate with injury, inflammation, metabolic disease [16-18]. More and more documents report that the level of $\mathrm{Hp}$ in plasmas goes up in many malignant tumors, such as ovarian cancer [19], breast cancer [20], renal cell cancer [21], colon carcinoma [22], acute leukemia [23], and 


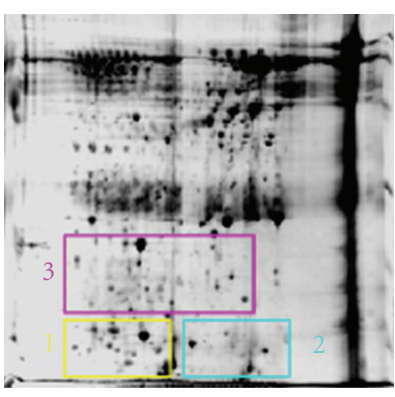

(a)

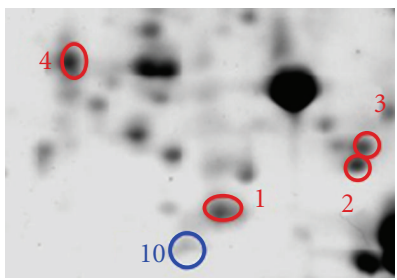

(a1)

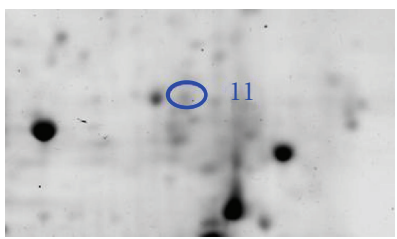

(a2)

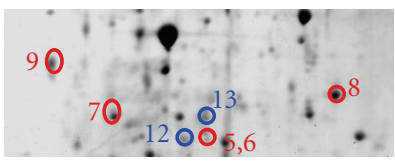

(a3)

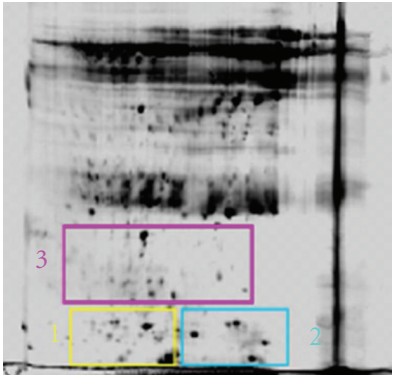

(b)

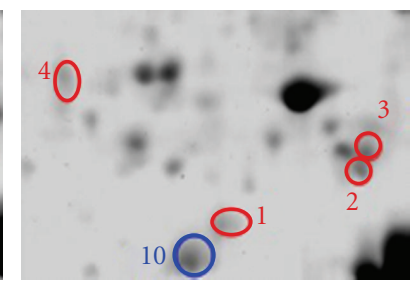

(b1)

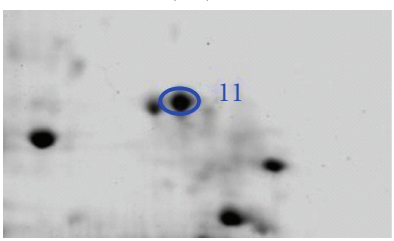

(b2)

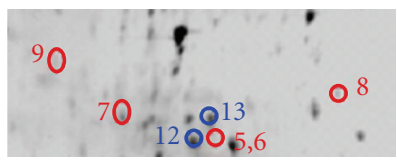

(b3)
Figure 4: Analysis of different expressed spots after and before lung cancer formation (a), ((a1), (a2), (a3)) Serum electropherogram of lung cancer; (b), ((b1), (b2), (b3)) Serum electropherogram before lung cancer formation (correspond to (a)). The different expression of 13 protein spots was obvious. The red signed spots were the highexpressed protein spots and the blue signed spots were the lowexpressed protein spots.

lung cancer [24]. Our research results were consistent with them. In our research, we found Hp greatly increased in lung cancer (the content of protein adds up to 8.328 times). Though maybe it does not belong to specific protein in lung cancer, owning to greatly increase level of $\mathrm{Hp}$ in the active stage of carcinoma and high sensitivity of immunology method, it could become an important check index for lung cancer diagnosis and monitoring and improve the sensitivity and specificity of early diagnosis in lung cancer when combining with other diagnostic indexes.

TTR also named preambumin and it is a tetrameric protein of about $55 \mathrm{kDa}$. The most of it is produced in liver and choroid plexus of brain. As for its function, TTR could transport the thyroid hormone $\mathrm{T}$ (4) and retinol through binding to the retinol binding protein. In addition, TTR has been established as a cryptic protease able to cleave ApoA-I in vitro. Some scholars have reported that TTR is involved in preventing A-Beta fibrillization by inhibiting

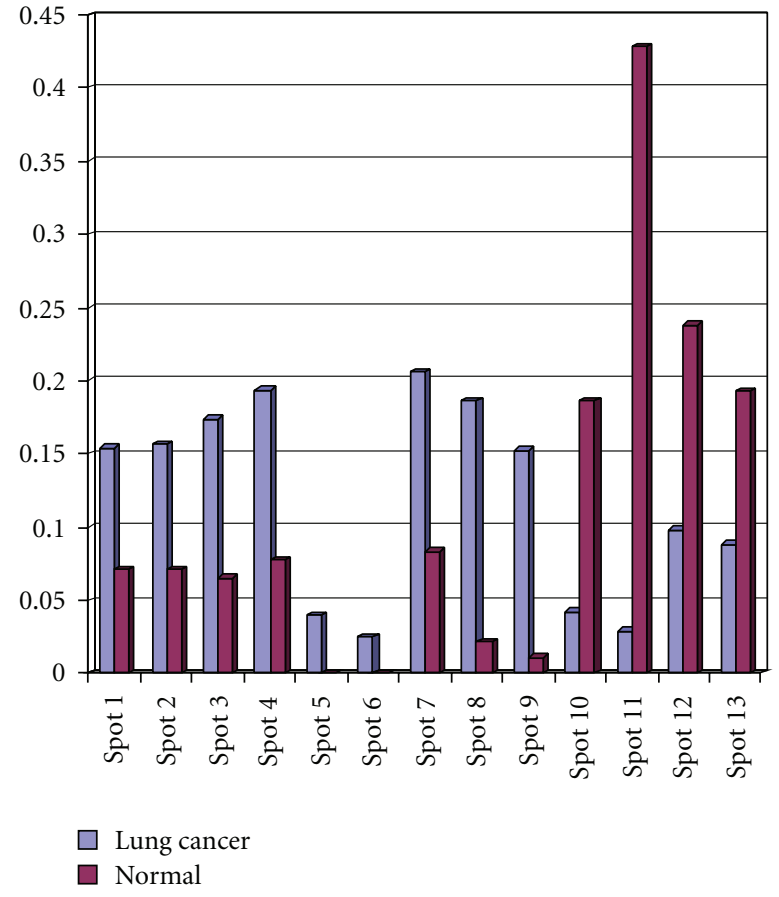

FIGURE 5: Comparison of content in 13 different expressed protein spots before and after lung cancer formation. The content of protein spots in plasma of lung cancer increased obviously in nos. 1, 2, 3, 4, 7, 8, 9 spots (more than twice) and decreased in nos. 10-13 spots (more than twice), and nos. 5-6 were the new protein spots.

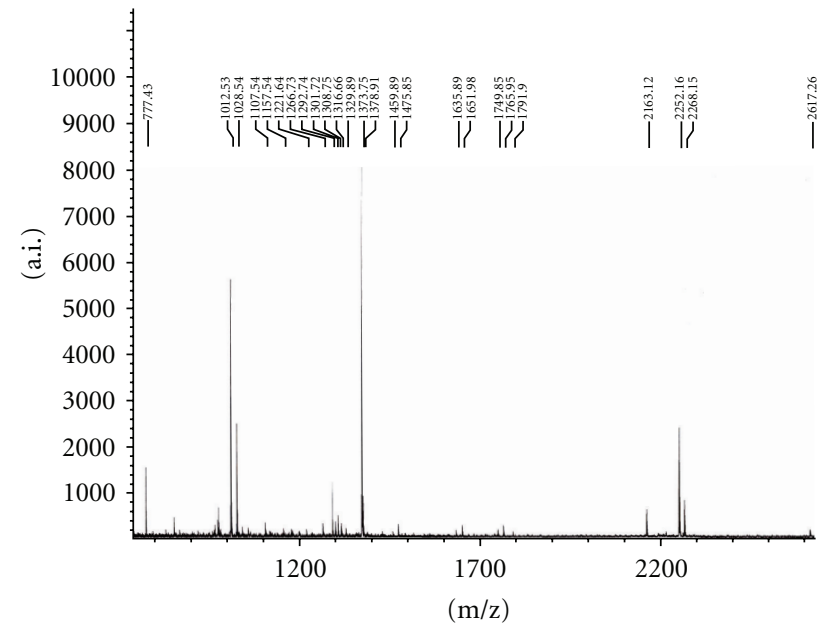

FIgure 6: Peptide mass fingerprinting map of protein spot 8.

and disrupting A-Beta fibrils, with consequent abrogation of toxicity [25]. TTR also plays an important role in nervous system physiology [26]. Costa et al. [25] further confirmed that as a protective mechanism in Alzheimer's disease (AD), TTR could serve as a protective molecule in this disease and prompted A-Beta proteolysis. It may be proved that TTR is a useful therapeutic agent in preventing or retarding the formation of cerebral amyloid plaque implicated in $\mathrm{AD}$ pathology. In the past, someone confirmed that in familial 

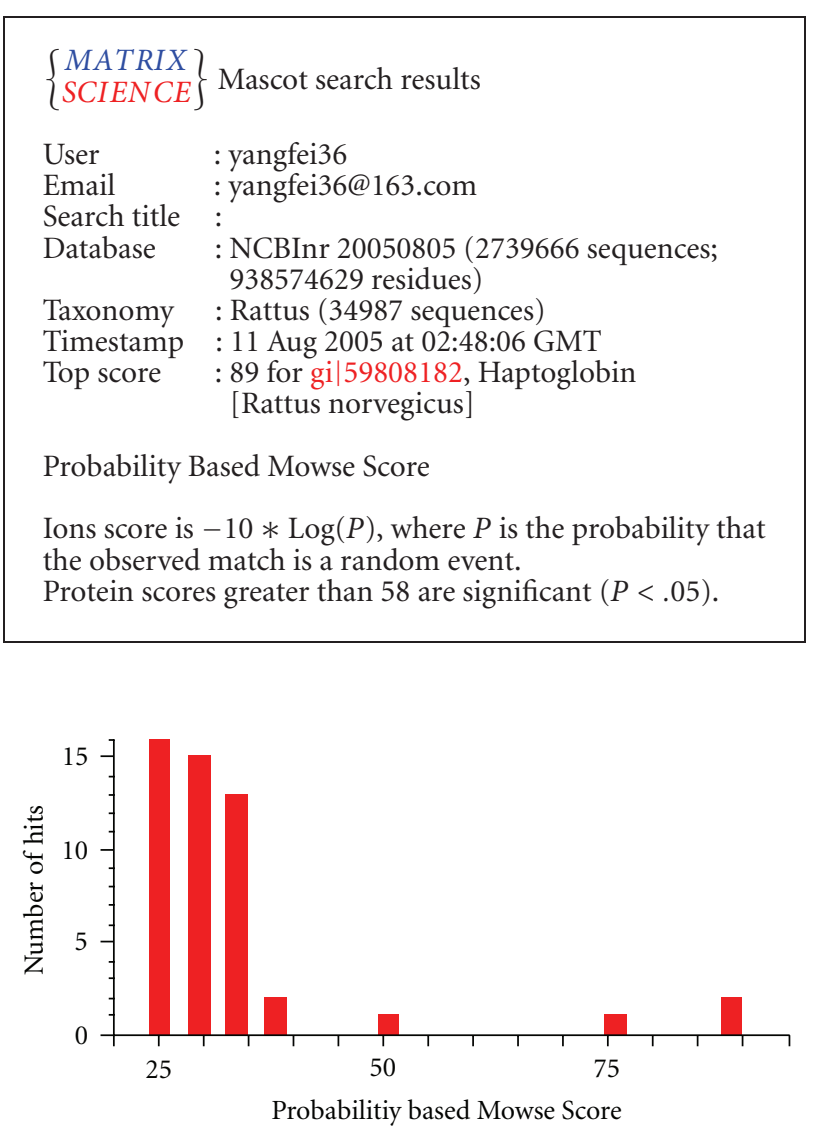

FIgURE 7: Mascot search results of protein spot 8 are Haptoglobin. Mowse Score was $89(>58, P<.05)$. When the figure was at the margin of shadow, Mowse Score was 58 and $P=.05$. If the score was more than $58, P<.05$.

amyloidotic polyneuropathy (FAP) which was associated with the abnormal extracellular tissue deposition of mutant transthyretin (TTR), inflammatory and apoptotic pathways both are triggered in the presymptomatic stages of the disease on the condition that nonfibrillar TTR deposits are present [27]. TTR Arg-83 may be just the new pathologic mutation in vitreous amyloidosis [28]. Meistermann et al. [29] also reported that transthyretin could serve as a biomarker for gentamicin-induced nephrotoxicity in rat. TTR tetramer makes up a component in normal beta-cell function. Conversion of TTR tetramer to monomer may relate to the development of beta-cell failure/destruction in type 1 diabetes [30]. In addition, TTR was upregulated in T2DM [31]. So we could see that TTR expression was associated with diabetes. At the same time, Bai et al. [32] gussed that the concentration of TTR maybe relates to the level of blood pressure, however, the concrete mechanism is still unclear. Some researches about protein nutrition indicated that TTR was a responsive nutrition index. The content of TTR quickly decreased when the proteins were insufficient and increased obviously when the amount of proteins gone up. Therefore, TTR was often used as an index of evaluating nutritional state, especially the nutrition and immunity state after operation $[33,34]$. So far, reports about

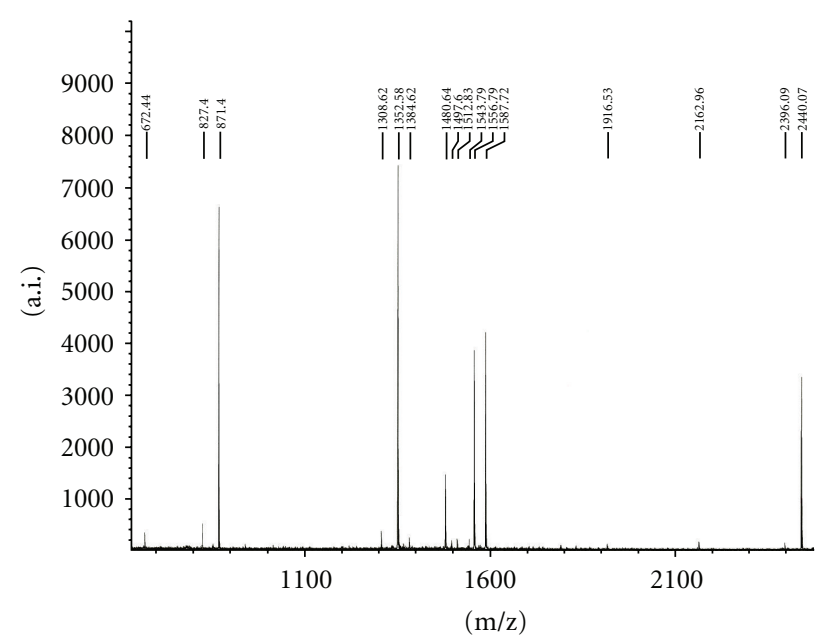

Figure 8: Peptide mass fingerprinting map of protein spot 11.

TTR relate to tumors mainly concentrate on liver cancer, ovarian cancer, leukemia. Gu et al. [35] first reported that the gene of TTR had close correlation to liver cancer, they found that the gene of TTR was expressed most highly in normal liver. The level of its mRNA greatly went down in liver cancer which the parenchyma was destroyed little. TTR was also considered as potential serum marker in early ovarian cancer [35-38]. In children with leukemia, the content of TTR and RBP in plasmas was greatly less than that in normal children. That difference also existed in different race, the melanoderm children were much less, and the lower level related to bad prognosis [39]. Some scholars [24] reported that TTR was overexpressed in blood serum in lung squamous cell carcinoma compared with normal lung. Our research also demonstrated that the content of TTR in plasmas greatly declined in the formation of lung cancer, it was consistent with their results. The amount of proteins in normal ones was 14 times bigger than that in lung cancer. So we could consider that the function and mechanism of decrease need further investigating.

TNFRS8 also named CD30, because Ki-1 monoclonal antibody was used in identifying it, therefore it named $\mathrm{Ki}-1$ as well. As a marker of activation of $\mathrm{T}$ and $\mathrm{B}$ lymphocytes, CD30 is a $120 \mathrm{kDa}$ surface phosphorylated glycoprotein [40] and it is predominantly overexpressed by the tumor cells (Hodgkin's and Reed-Sternberg cells) of classical Hodgkin's lymphoma (cHL) and those of anaplastic large cell lymphoma (ALCL) in classical Hodgkin lymphoma [41]. It is well known that CD30 expression is not unique to Hodgkin lymphoma and Anaplastic Large Cell Lymphoma (ALCL) because of its expression in mediastinal large B cell lymphoma, a subset of nodal diffuse large cell lymphoma, large cells in follicular lymphoma, nodal and cutaneous diffuse large B cell lymphoma, peripheral $\mathrm{T}$ cell lymphoma, embryonal carcinoma, and other nonlymphoid cells and neoplasms [40]. The expression of CD30 was also associated with pregnancy. Kusanovic [42] found that the content of maternal serum soluble CD30 increased in normal pregnancy, however, it decreased in preeclampsia and it is 
small for gestational age pregnancies. At the same time, Lambropoulou et al. [43] proved that during the second trimester, CD30 was expressed highly in many medullary thymic epithelial cells (TECs) and Hassall's corpuscles, but small numbers of CD30 ${ }^{+}$TECs were showed during the late first trimester. Large number of researches proved that if CD30 crosslinked with CD30L, activated signal may be issued. So it promoted the transmission of intracellular information. Because that information could be positive or negative signal, consequently, it resulted in cellular growth was inhibited or cellular apoptosis [44], cellular hyperplasia or differentiation, secretion of cytokine, and so on. Wright et al. [45] further confirmed that in ALCL cells, the stimulation of CD30 elicits p21 (waf1)-mediated arrest through the canonical but not the alternative NF-kappaB pathway. Gerli et al. [46] reported that there were many $\mathrm{CD} 0^{+} \mathrm{CD}^{+}, \mathrm{CD} 0^{+} \mathrm{CD} 8^{+}$cell in joint synovial fluid of patient with RA, large amount of sCD30 existed in peripheral blood and affected joint synovial fluid, especially in active stage, it had direct relation with the titre of RAF. It hinted that there was relationship between CD30 cell, sCD30 cell, and $\mathrm{TH} 2$ reactive disease. In addition, the increase of CD30 cells and SCD30 cells was detected in acute stage of $\mathrm{TH} 2$ reactive illness, such as SLE, scleroderma, specifical scytitis. Many researches showed the amount of sCD30 increased in active stage of chronical viral hepatitis $\mathrm{B}$ and there were striking differences compared with normal controls and virus carries, hinting the activity of $\mathrm{TH} 2$ cytokine in active stage of hepatitis [47, 48]. In Hodgkin's disease, the level of serum sCD30 abnormally increased in active stage in nontreated patients. The extent of increase related to the stage of illness and general symptoms. It could be an independent prognosis index, the higher of sCD30, the worser of prognosis [49]. In ALCL, the great increase of serum sCD30 was observed as well. In our research, sCD30 was detected in composite plasmas after the formation of lung cancer. There was not sCD30 in normal controls, indicating that the amount of sCD30 went up indeed in forming lung cancer, so far, the mechanism of increase is not clear. Hargreaves et al. [50] guessed that it was possible that the function of sCD30 brought into full play by blocking the cross-link of CD30 and CD30L.

Recently, researches in lung cancer demonstrated that a series of complicated molecular events involved in carcinogenesis, such as activation of oncogene and inactivation of antioncogene. Proteins are the executants of gene function indeed. Proteomics aim at the large-scale analysis of protein in tissues, cell, and plasmas, including protein expression, posttranslational modification, and interaction of proteins. Proteomics has become a hot spot in lung cancer research.

By applying the proteomics technology, many researchers had found a large number of proteins as the candidate tumor markers from blood plasmas in lung cancers. By comparing protein expression levels among 93 lung adenocarcinomas and 10 uninvolved lung samples, Chen et al. [51] found that nine different enzyme proteins were identified by the method of 2D-PAGE and MALDI-MS or peptide sequencing. All of them increased obviously in the lung adenocarcinomas, including the antioxidant enzyme

\begin{tabular}{|c|c|}
\hline$\left\{\begin{array}{l}\text { MATRIX } \\
\text { SCIENCE }\end{array}\right\}$ & Mascot search results \\
\hline User & : yangfei36 \\
\hline Email & :yangfei36@163.com \\
\hline Search title & \\
\hline Database & $\begin{array}{l}\text { : NCBInr } 20050805 \text { (2739666 sequences; } \\
938574629 \text { residues) }\end{array}$ \\
\hline Taxonomy & : Rattus (34987 sequences) \\
\hline Timestamp & : 11 Aug 2005 at 12:33:59 GMT \\
\hline Top score & $\begin{array}{l}110 \text { for gi| } 3212535 \text {, Chain D, Rat } \\
\text { Transthyretin }\end{array}$ \\
\hline \multicolumn{2}{|c|}{ Probability Based Mowse Score } \\
\hline \multicolumn{2}{|c|}{$\begin{array}{l}\text { Ions score is }-10 * \log (P) \text {, where } P \text { is the probability that } \\
\text { the observed match is a random event. } \\
\text { Protein scores greater than } 58 \text { are significant }(P<.05) \text {. }\end{array}$} \\
\hline
\end{tabular}

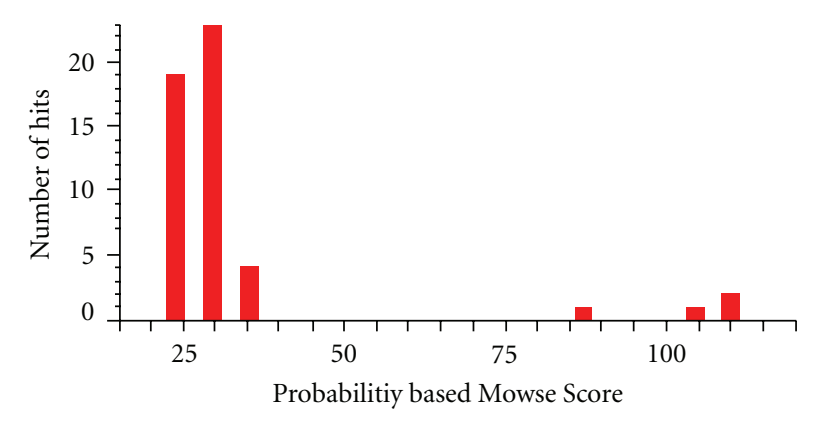

FIGURE 9: Mascot search results of protein spot 11 are Transthyretin (TTR). Mowse Score is $110(>58, P<.05)$.

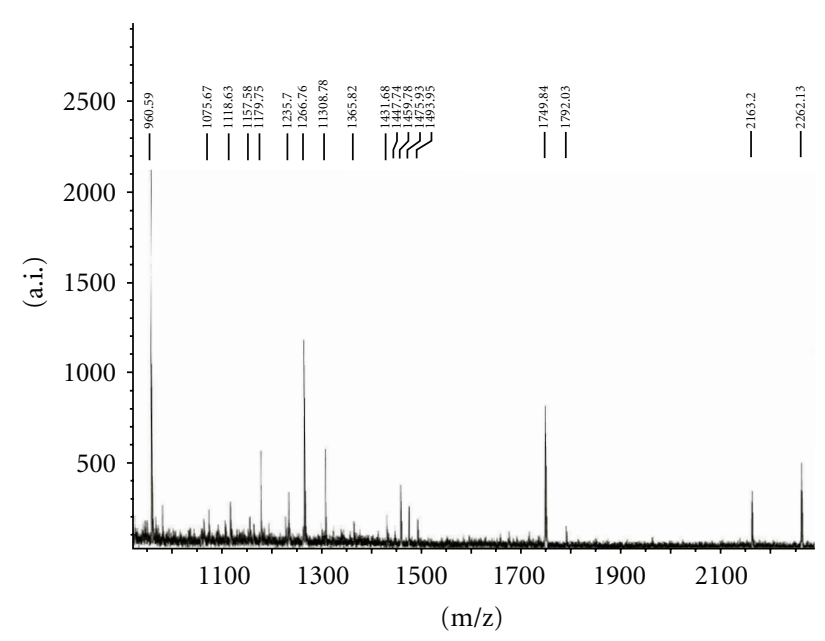

FIgURe 10: Peptide mass fingerprinting map of protein spot 5.

AOE372, ATP5D, B4GALT, cytosolic inorganic pyrophosphatase (PPase), GRP58, GSTM4, P4HB, TPI, and ubiquitin hiolesterase. Brichory et al. [52] identify proteins that commonly induce an antibody response in lung cancer by making use of proteomic approach; protein gene product 9.5 (PGP 9.5) was detected in serum. When they took advantage of A549 lung adenocarcinoma cell line, they have 


\begin{tabular}{|c|c|}
\hline$\left\{\begin{array}{l}\text { MATRIX } \\
\text { SCIENCE }\end{array}\right.$ & Mascot search results \\
\hline User & : yangfei36 \\
\hline Email & :yangfei36@163.com \\
\hline Search title & $:$ \\
\hline Database & $\begin{array}{l}\text { NCBInr } 20050805 \text { (2739666 sequences; } \\
\text { 938574629 residues) }\end{array}$ \\
\hline Taxonomy & : Rattus (34987 sequences) \\
\hline Timestamp & : 10 Aug 2005 at 06:15:02 GMT \\
\hline Top score & $\begin{array}{l}\text { : } 65 \text { for gi| } 9507193 \text {, tumor necrosis } \\
\text { factor receptor superfamily, } \\
\text { member } 8 \text { [Rattus norvegicus] }\end{array}$ \\
\hline \multicolumn{2}{|c|}{ Probability Based Mowse Score } \\
\hline \multicolumn{2}{|c|}{$\begin{array}{l}\text { Ions score is }-10 * \log (P) \text {, where } P \text { is the probability that } \\
\text { the observed match is a random event. } \\
\text { Protein scores greater than } 58 \text { are significant }(P<.05) \text {. }\end{array}$} \\
\hline
\end{tabular}

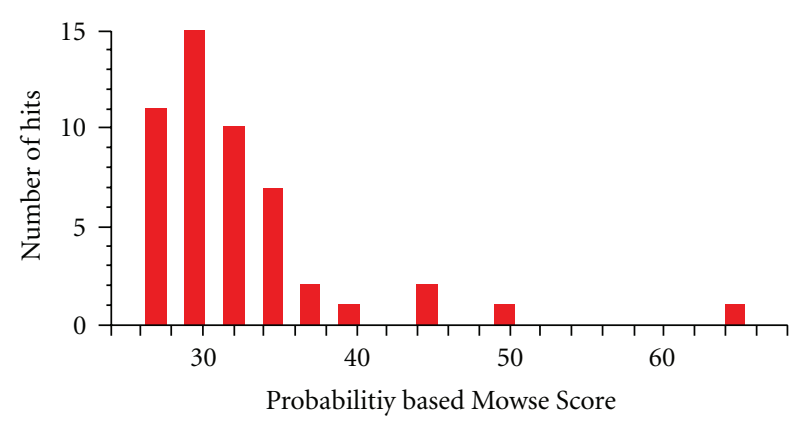

FIgURE 11: Mascot search results of protein spot 5 are TNFRS8. Mowse Score is $110(>58, P<.05)$.

proved that PGP 9.5 existed at the cell surface as well as secreted. Therefore, the discovery of PGP 9.5 antigen and/or antibodies in serum of patients with lung cancer showed that PGP 9.5 may be used in lung cancer screening and diagnosis. Chatterji and Borlak [53] found that eight proteins were also identified in serum though they were identified in tissue of lung tumor bearing mice. A total of 50 proteins were identified in serum, some of which were specifically regulated or exclusively expressed either in tumor bearing or wild-type mice. What is more, they revealed that alpha1-antitrypsin (A1AT) and alpha-2-macroglobulin (A2MG) were upregulated in the serum proteome of 12 months old mice. In cancer tissue, A1AT was increased in 1-monthold mice as well. However, the expression of A2MG was decreased in 1-month-old mice. Hemoglobin subunit alpha went up in serum samples of lung tumor bearing mice (12 months). They found MUPs to be upregulated in early and late stages of tumor development. So MUPs maybe serve as a biomarker for the diagnosis of lung cancer. They discovered the expression of transthyretin to be gone up in 1 month and repressed in 12 months old tumor bearing mice. Thus they suggested that their in-depth validation could become biomarker candidates for the identification of lung adenocarcinomas. Serological proteome analysis (SERPA) of ten hLSC tissues was performed by Li et al.
[54] to identify the tumor-associated antigens. The results showed $36 \pm 8$ differential proteins reactive with patients' autologous serum, 14 proteins of them were identified. In addition, six of the 14 proteins, alpha enolase, pre- $B$ cell-enhancing factor precursor, triosephosphate isomerase, phosphoglycerate mutase 1, fructose-bisphosphate aldolase $\mathrm{A}$, and guanine nucleotide-binding protein beta subunitlike protein were also increased in hLSCs in the comparative proteomic research, therefore, it indicated that these 6 hLSC-associated antigens can be applied in diagnosis and therapy of hLSC. Autoantibodies against triosephosphate isomerase (Tim) and superoxide dismutase [Mn] (MnSOD) were detected by Yang et al. [55] in serum from over 20\% patients with LSC but none from the normal controls. Their results suggested that autoantibody and antigen of Tim and MnSOD may also be potential application for screening and diagnosis of the lung squamous carcinoma. At the same time, Lisa et al. [56] found that five truncation forms of serum amyloid A protein precursor and serum amyloid Al isoform 2 as a part of the components of the serum proteomic biomarkers of lung cancer. Differential expression of some of them correlated to the diagnosis of lung adenocarcinoma. These results indicated that it was possible that the serum proteomic signature of lung cancer was the part of the result of specific proteolytic activity in the serum and/or in lung tumors. Luo et al. [57] built up the protein configuration in the plasmas of lung adenocarcinoma using the method of the SELDI-TOF-MS technology and discovered 5 special protein peaks which highly expressed in lung adenocarcinoma. In addition, Liao et al. [58] captured serum proteins in lung adenocarcinoma by the technology of WCX2 chip and found 10 different expressed proteins in which 6 overexpressed proteins and 4 underexpressed proteins. However, a large number of lung cancers and normal people were essential to prove these differently expressed proteins and special expressed spectral patterns, to identify and show their functions in the formation of tumor.

Due to direct examination of the molecular machinery of cell physiology, including protein expression, sequence variations and isoforms, posttranslational modification, and protein-protein complexes, proteomics has the self-evident advantages over genomic-based assays. Nonetheless, there are certain disadvantages as well, for instance, (i) sample collection, preparation, and analysis need rigorous requirement, (ii) there are no amplification procedures which similar to PCR that could enable assay to improve making use of the limited biological starting material, (iii) we are short of purification strategies which could enrich samples for intended work (e.g., phosphoprotein analysis), and (iv) necessary costs are insufficient for staffing and equipping shared resources or clinical laboratory which can be able to perform the required assays [59]. Though there are some limitations in the technology of proteomics, with the maturation of proteomic technique and improvement of sample pretreatment and preparation technique. We believe its application in analysis of blood plasmas will become more and more popular and become a new method for clinical diagnosis and illness monitoring. In addition, the screening and identification of tumor markers will step into a new stage. In a word, the 
research tactics in proteomics of tumor markers will bring about far-reaching extensive effects for lung cancer diagnosis and treatment. It will quicken the process of researches in lung cancer as well as making a great contribution to win a victory in human being's flight with tumor.

\section{Conclusion}

In our experiment, we made the rat plasmas derived from lung cancers and the normal controls to be our targets of observation and comparison. By regulating and optimizing all conditions of 2DE technique, we finally obtained satisfactory 2DE patterns in which the 700 serum proteins were detected from the lung cancers and the normal controls. In addition, the 141 differently expressed protein spots were acquired by image screen and image analysis. The 82 spots were overexpressed in lung cancer and the 59 spots were overexpressed in normal controls. At the same time, we successfully identified three proteins including HP, TTR, and TNFRS8 by making use of the MALDI-TOF-MS to analyze the 13 differently expressed protein spots. The increase of HP, which belongs to APP, hinted the appearance of stress reaction in the process of forming lung cancer. In addition, the decrease of TTR, which shows the nutritional state, hinted the changes of nutritional state. As a member of tumor necrosis factor super family, TNFRS 8 could regulate the function of immunity and hinted a series of changes of immunity state in the process of forming lung cancer. In a conclusion, (i) the plasmas proteins were separated successfully for proteome research of lung cancer by the optimized 2DE technique. (ii) There were the differently expressed proteins between the normal plasmas and the lung cancer plasmas. (iii) The differentially expressed proteins in plasmas of rat lung cancer provided the evidence for keeping searching the markers for lung cancer diagnosis and therapy.

\section{Acknowledgments}

The authors gratefully thank the Health Department of Hubei Province (no. 301131448) for financial supports and thank the Medical school in Wuhan University for spiritual support.

\section{References}

[1] Y. Qin, B. S. Zhou, Z. Y. Xu, and D. Wu, "Inspiration of increasing trend in lung cancer morbility for investigating etiopathogenisis of lung cancer," Chinese Journal of Health Statistics, vol. 18, no. 2, pp. 121-123, 2001.

[2] W. T. John, M. Moulay, and V. Robert, "Transthoracic needle biopsy," Radiologic Clinics of North America, vol. 338, no. 2, pp. 235-266, 2000.

[3] N. L. Anderson and N. G. Anderson, "Proteome and proteomics: new technologies, new concepts, and new words," Electrophoresis, vol. 19, no. 11, pp. 1853-1861, 1998.

[4] S. B. Giorgianni, "Proteome analysis by two-dimensional gel electrophoresis and mass spectrometry: strengths and limitations," Trends in Analytical Chemistry, vol. 22, no. 5, pp. 273-281, 2003.
[5] H. S. Tian, M. Q. Liu, and W. Q. Gao, "Induction of lung carcinoma by intralobar bronchial instillation of iodized oil rats," Chinese Medical Journal, vol. 97, no. 1, p. 36, 1984.

[6] M. Liu, L. Yu, Q. Shu, et al., "Effect of superoxide dismutase and diethyldithiocarbamate on the induction of squamous cell carcinoma of lung with methylcholanthrene in rats," Chinese Journal of Oncology, vol. 16, no. 4, pp. 269-272, 1994.

[7] D.-Z. Wang, L. Lin, L. L. Chan, and H.-S. Hong, "Comparative studies of four protein preparation methods for proteomic study of the dinoflagellate Alexandrium sp. using twodimensional electrophoresis," Harmful Algae, vol. 8, no. 5, pp. 685-691, 2009.

[8] X. H. Li, D. J. Cheng, M. Jiang, et al., "Expression of p53, $m d m 2, \mathrm{k}$-ras and PCNA gene during carcinogenesis in experimental lung cancer," Cancer, vol. 20, no. 9, pp. 921-925, 2001.

[9] X. H. Li, M. Liu, L. Diao, et al., "Microdissection and PCRSSCP detected mutation and expression of p53 and K-ras gene in carcinogenesis and development of induced rat lung carcinoma," Chinese Journal of Pathology, vol. 31, no. 4, pp. 331-336, 2002.

[10] L. N. Tan and J. H. Huang, "Recent advances in the investigation of haptoglobin," Journal of International Pathology and Clinical Medicine, vol. 26, no. 1, pp. 0043-0004, 2006.

[11] W. E. Friedrichs, A. L. Navarijo-Ashbaugh, B. H. Bowman, and F. Yang, "Expression and inflammatory regulation of haptoglobin gene in adipocytes," Biochemical and Biophysical Research Communications, vol. 209, no. 1, pp. 250-256, 1995.

[12] O. Mi-Kyung, P. Seon-Joo, K. Nam-Joon, and K. In-Sook, "Short communication: protein kinase-c-delta stimulates haptoglobin secretion," Journal of Biochemical and Molecular Biology, vol. 40, no. 1, pp. 130-134, 2007.

[13] J. D’Armiento, S. S. Dalal, and K. Chada, "Tissue, temporal and inducible expression pattern of haptoglobin in mice," Gene, vol. 195, no. 1, pp. 19-27, 1997.

[14] K. Theilgaard-Mönch, L. C. Jacobsen, M. J. Nielsen, et al., "Haptoglobin is synthesized during granulocyte differentiation, stored in specific granules, and released by neutrophils in response to activation," Blood, vol. 108, no. 1, pp. 353-361, 2006.

[15] R. Vormittag, T. Vukovich, C. Mannhalter, et al., "Haptoglobin phenotype2-2 as a potential new risk of spontaneous venous thromboembolism," Haematologia, vol. 90, no. 11, pp. 577$561,2005$.

[16] T. B. Larssen, J. Rørvik, A. Horn, et al., "Biochemical and cytologic analysis of cystic contents in benign nonparasitic symptomatic hepatic cysts before and after ethanol sclerotherapy," Acta Radiologica, vol. 45, no. 5, pp. 504-509, 2004.

[17] M. K. Heliövaara, A. M. Teppo, S. L. Karonen, J. A. Tuominen, and P. Ebeling, "Plasma IL-6 concentration is inversely related to insulin sensitivity, and acute-phase proteins associate with glucose and lipid metabolism in healthy subjects," Diabetes, Obesity and Metabolism, vol. 7, no. 6, pp. 729-736, 2005.

[18] P. Trayhurn, "Endocrine and signalling role of adipose tissue: new perspectives on fat," Acta Physiologica Scandinavica, vol. 184, no. 4, pp. 285-293, 2005.

[19] N. Ahmed, K. T. Oliva, G. Barker, et al., "Proteomic tracking of serum protein isoforms as screening biomarkers of ovarian cancer," Proteomics, vol. 5, no. 17, pp. 4625-4636, 2005.

[20] A. Gonçalves, B. Esterni, F. Bertucci, et al., "Postoperative serum proteomic profiles may predict metastatic relapse in high-risk primary breast cancer patients receiving adjuvant chemotherapy," Oncogene, vol. 25, no. 7, pp. 981-989, 2006. 
[21] J. Tolson, R. Bogumil, E. Brunst, et al., "Serum protein profiling by SELDI mass spectrometry: detection of multiple variants of serum amyloid alpha in renal cancer patients," Laboratory Investigation, vol. 84, no. 7, pp. 845-856, 2004.

[22] R. S. Bresalier, J. C. Byrd, D. Tessler, et al., "A circulating ligand for galectin-3 is a haptoglobin-related glycoprotein elevated in individuals with colon cancer," Gastroenterology, vol. 127, no. 3, pp. 741-748, 2004.

[23] J. Y. Kwak, T. Z. Ma, M. J. Yoo, et al., “The comparative analysis of serum proteomes for the discovery of biomarkers for acute myeloid leukemia," Experimental Hematology, vol. 32, no. 9, pp. 836-842, 2004.

[24] G. J. Nie, J. H. Zhou, M. Y. Li, et al., "Different proteomic research between lung squamous cell carcinoma and normal blood serum," Progress in Biochemistry and Biophysics, vol. 35, no. 3, pp. 349-355, 2008.

[25] R. Costa, F. Ferreira-da-Silva, M. J. Saraiva, and I. Cardoso, "Transthyretin protects against A-beta peptide toxicity by proteolytic cleavage of the peptide: a mechanism sensitive to the kunitz protease inhibitor," PLOS ONE, vol. 3, no. 8, article e2899, 2008.

[26] A. F. Nunes, M. J. Saraiva, and M. M. Sousa, "Transthyretin knockouts are a new mouse model for increased neuropeptide Y," The FASEB Journal, vol. 20, no. 1, pp. 166-168, 2006.

[27] B. Macedo, A. R. Batista, J. B. do Amaral, and M. J. Saraiva, "Biomarkers in the assessment of therapies for familial amyloidotic polyneuropathy," Molecular Medicine, vol. 13, no. 11-12, pp. 584-591, 2007.

[28] L. Chen, L. Lü, P. Zhang, Y. Li, and J. Lin, "Transthyretin Arg83 mutation in vitreous amyloidosis," Eye Science, vol. 24, no. 1, pp. 65-67, 2008.

[29] H. Meistermann, J. L. Norris, H. R. Aerni, et al., "Biomarker discovery by imaging mass spectrometry: transthyretin is a biomarker for gentamicin-induced nephrotoxicity in rat," Molecular and Cellular Proteomics, vol. 5, no. 10, pp. 18761886, 2006.

[30] E. Refai, N. Dekki, S. N. Yang, et al., "Transthyretin constitutes a functional component in pancreatic $\beta$-cell stimulussecretion coupling," Proceedings of the National Academy of Sciences of the United States of America, vol. 102, no. 47, pp. 17020-17025, 2005.

[31] T. Sundsten, M. Eberhardson, M. Göransson, and P. Bergsten, "The use of proteomics in identifying differentially expressed serum proteins in humans with type 2 diabetes," Proteome Science, vol. 4, article 22, 2006.

[32] X. S. Bai, L. L. Gong, S. H. Zhang, et al., "The relationship between transthyretin and the level of blood pressure," Acta Academiae Medicinae Jiangxi, vol. 48, no. 3, pp. 40-42, 2008.

[33] H. Ihara, T. Matsumoto, Y. Shino, et al., "Selective use of transthyretin and retinol-binding protein as markers in the postoperative assessment of protein nutritional status," Journal of Clinical Laboratory Analysis, vol. 17, no. 1, pp. 1-5, 2003.

[34] D. S. Strauss, "Nutritional regulation of visceral markers in rat liver and cultured hepatoma cells," Clinical Chemistry and Laboratory Medicine, vol. 40, no. 12, pp. 1274-1280, 2002.

[35] J. R. Gu, H. Q. Jiang, L. P. He, et al., "Transthyretin (prealbumin) gene in human primary hepatic cancer," Science in China B, vol. 34, no. 11, pp. 1312-1318, 1991.

[36] A. C. Kuesel, T. Kroft, M. Prefontaine, and I. C. Smith, "Lipoprotein(a) and CA125 levels in the plasma of patients with benign and malignant ovarian disease," International Journal of Cancer, vol. 52, no. 3, pp. 341-346, 1992.
[37] C. G. Mahlck and K. Granvist, "Plasma prealbumin in women with epithelial ovarian carcinoma," Gynecologic and Obstetric Investigation, vol. 37, no. 2, pp. 135-140, 1994.

[38] Z. Zhang, R. C. Bast Jr., Y. Yu, et al., "Three biomarkers identified from serum proteomic analysis for the detection of early stage ovarian cancer," Cancer Research, vol. 64, no. 16, pp. 5882-5890, 2004.

[39] S. Kuvibidila, L. Yu, R. Gardner, M. Velez, D. Ode, and R. P. Warrier, "Association between increased levels of TNF- $\alpha$, decreased levels of prealbumin and retinol-binding protein, and disease outcome," Journal of the National Medical Association, vol. 92, no. 10, pp. 485-491, 2000.

[40] M. Zhou, F. M. Fadlelmola, J. B. Cohn, B. Skinnider, R. D. Gascoyne, and D. Banerjee, "Constitutive overexpression of a novel $21 \mathrm{kDa}$ protein by Hodgkin Lymphoma and Aggressive Non-Hodgkin Lymphomas," Molecular Cancer, vol. 7, no. 12, 2008.

[41] B. Hirsch, M. Hummel, S. Bentink, et al., "CD30-induced signaling is absent in Hodgkin's cells but present in anaplastic large cell lymphoma cells," The American Journal of Pathology, vol. 172, no. 2, pp. 510-520, 2008.

[42] J. P. Kusanovic, R. Romero, S. S. Hassan, et al., "Maternal serum soluble CD30 is increased in normal pregnancy, but decreased in preeclampsia and small for gestational age pregnancies," Journal of Maternal-Fetal and Neonatal Medicine, vol. 20, no. 12, pp. 867-878, 2007.

[43] M. Lambropoulou, D. Tamiolakis, I. Venizelos, et al., "CD30 (Ber-H2) expression by thymocytes and thymic epithelial cells during the late first and second trimester of gestation: an immunohistochemical and in situ hybridization (ISH) study," Medical Science Monitor, vol. 13, no. 12, pp. 280-285, 2007.

[44] H. Kamiyama, K. Kurosaki, M. Kurimoto, et al., "Herpes simplex virus-induced, death receptor-dependent apoptosis and regression of transplanted human cancers," Cancer Science, vol. 95, no. 12, pp. 990-998, 2004.

[45] C. W. Wright, J. M. Rumble, and C. S. Duckett, "CD30 activates both the canonical and alternative NF- $\kappa$ B pathways in anaplastic large cell lymphoma cells," The Journal of Biological Chemistry, vol. 282, no. 14, pp. 10252-10262, 2007.

[46] R. Gerli, C. Muscat, O. Bistoni, et al., "High levels of the soluble form of CD30 molecule in rheumatoid arthritis (RA) are expression of $\mathrm{CD} 30^{+} \mathrm{T}$ cell involvement in the inflamed joints," Clinical and Experimental Immunology, vol. 102, no. 3, pp. 547-550, 1995.

[47] F. Monsalve-de Castillo, T. A. Romero, J. Estévez, et al., "Concentrations of cytokines, soluble interleukin-2 receptor, and soluble CD30 in sera of patients with hepatitis B virus infection during acute and convalescent phases," Clinical and Diagnostic Laboratory Immunology, vol. 9, no. 6, pp. 13721375, 2002.

[48] F. Monsalve C, T. Romero-A, J. Estévez, L. Costa, and D. Callejas, "Serum levels of soluble CD30 molecule in hepatitis B virus infection," Revista Medica de Chile, vol. 129, no. 11, pp. 1248-1252, 2001.

[49] M. C. Gilffillan, P. J. Noel, E. R. Podack, S. L. Reiner, and C. B. Thompson, "Expression of the costimulatory receptor CD30 is regulated by both CD28 and cytokines," Journal of Immunology, vol. 160, no. 5, pp. 2180-2187, 1998.

[50] P. G. Hargreaves and A. Al-Shamkhani, "Soluble CD30 binds to CD153 with high affinity and blocks transmembrane signaling by CD30," European Journal of Immunology, vol. 32, no. 1, pp. 163-173, 2002. 
[51] G. Chen, T. G. Gharib, C. C. Huang, et al., "Proteomic analysis of lung adenocarcinoma: identification of a highly expressed set of proteins in tumors," Clinical Cancer Research, vol. 8, no. 7, pp. 2298-2305, 2002.

[52] F. Brichory, D. Beer, F. Le Naour, T. Giordano, and S. Hanash, "Proteomics-based identification of protein gene product 9.5 as a tumor antigen that induces a humoral immune response in lung cancer," Cancer Research, vol. 61, no. 21, pp. 79087912, 2001.

[53] B. Chatterji and J. Borlak, "Serum proteomics of lung adenocarcinomas induced by targeted overexpression of $c$ raf in alveolar epithelium identifies candidate biomarkers," Proteomics, vol. 7, no. 21, pp. 3980-3991, 2007.

[54] C. Li, Z. Q. Xiao, Z. Chen, et al., "Proteome analysis of human lung squamous carcinoma," Proteomics, vol. 6, no. 2, pp. 547558, 2006.

[55] F. Yang, Z. Q. Xiao, X. Z. Zhang, et al., "Identification of tumor antigens in human lung squamous carcinoma by serological proteome analysis," Journal of Proteome Research, vol. 6, no. 2, pp. 751-758, 2007.

[56] Z. Lisa, R. Jamshedur, Y. Pinar, et al., "Truncation forms of serum amyloid A contribute to a serum proteomic signature of lung cancer," in Proceedings of the American Association of Cancer Research, vol. 46, 2005.

[57] X. Y. Luo, H. Q. Chen, J. H. Zhou, et al., "Proteomic patterns in serum of lung adenocarcinoma patients and its correlation with clinical TNM stage," Chinese Journal of Thoracic and Cardiovascular Surgery, vol. 22, no. 2, pp. 112-114, 2006.

[58] P. Liao, W. J. Wang, P. Y. Zhu, et al., "Detection of serum protein biomarkers by surface-enhanced laser desorption and ionization time of flight mass spectrometry(SELDI-TOF-MS) in patients with lung adenocarcinoma," J China Tumor, vol. 15, no. 4, pp. 258-261, 2006.

[59] J. M. Koomen, E. B. Haura, G. Bepler, et al., "Proteomic contributions to personalized cancer care," Molecular and Cellular Proteomics, vol. 7, no. 10, pp. 1780-1794, 2008. 


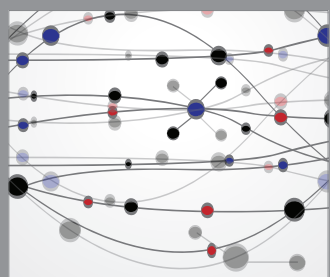

The Scientific World Journal
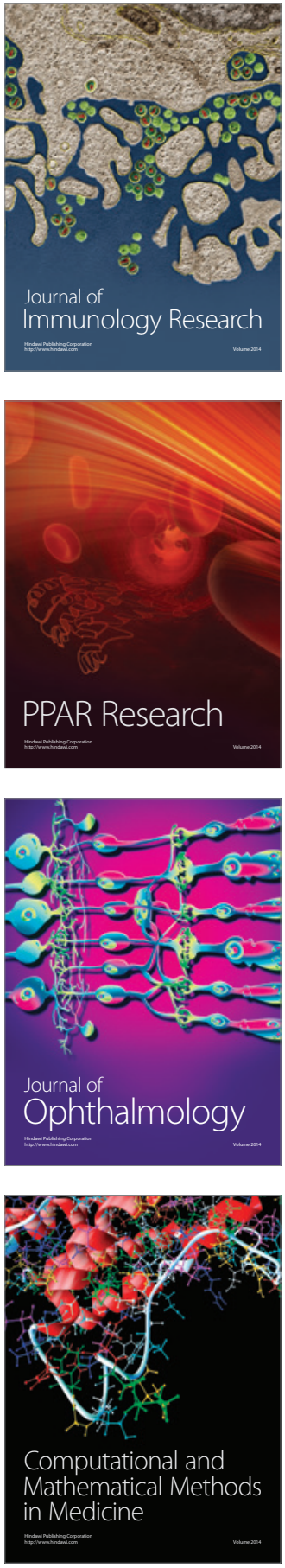

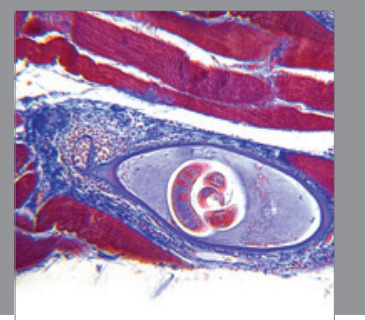

Gastroenterology

Research and Practice
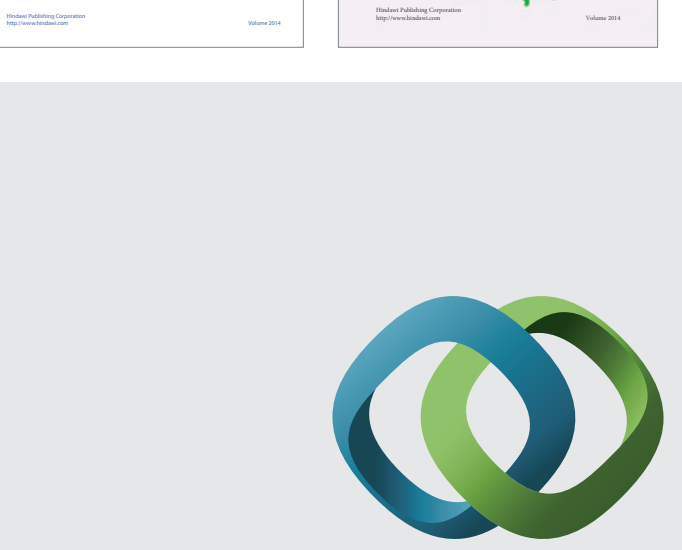

\section{Hindawi}

Submit your manuscripts at

http://www.hindawi.com
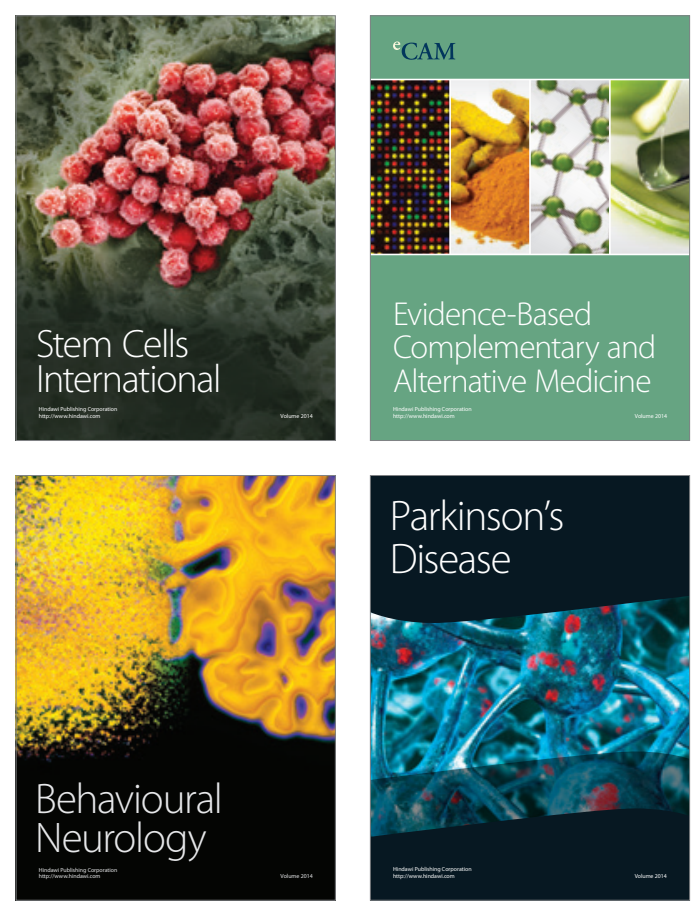

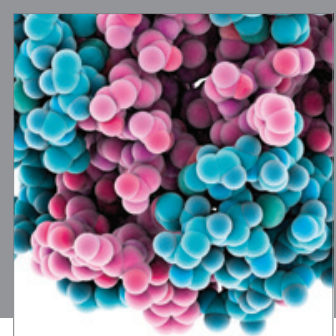

Journal of
Diabetes Research

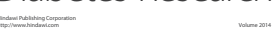

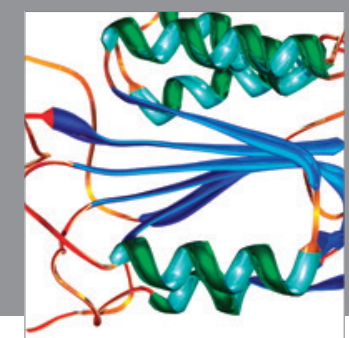

Disease Markers
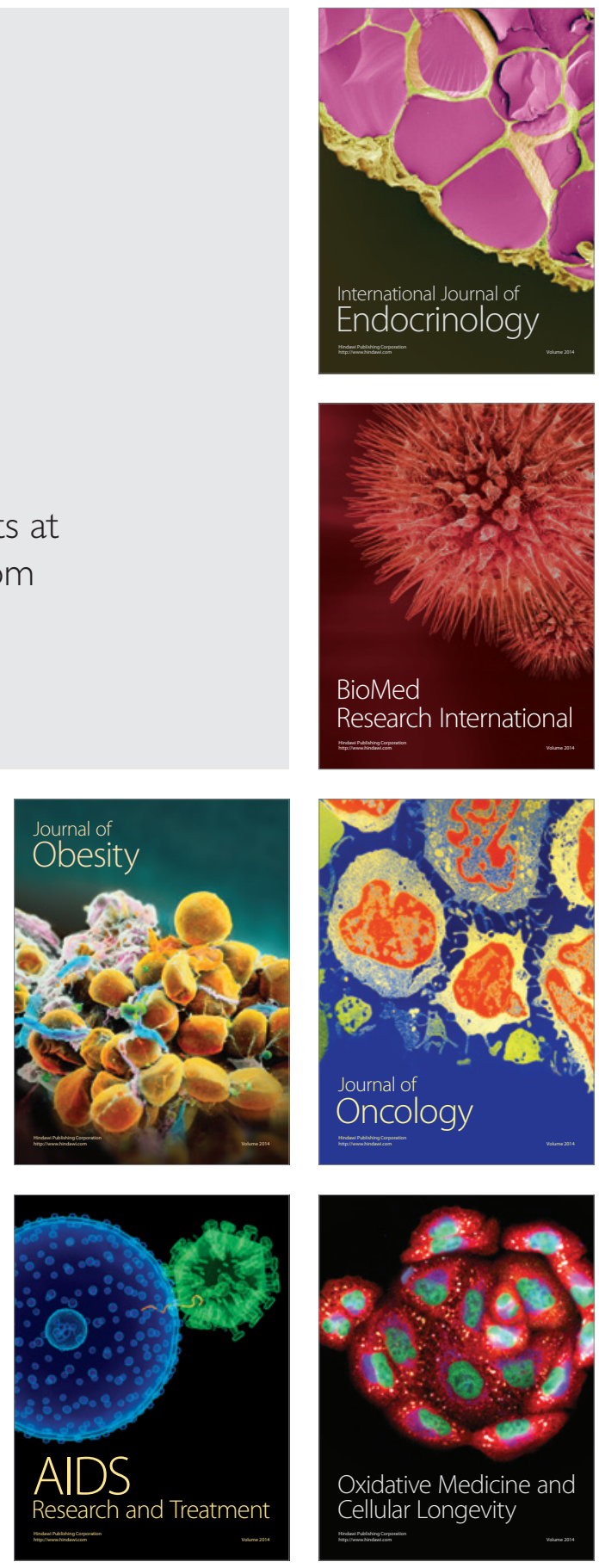